\title{
Svensk blick på nordisk litteraturhistoria
}

\section{Margareta Petersson \& Rikard Schönström (red.), Nordens litteratur. Lund: Student- litteratur 2017, $574 \mathrm{~S}$.}

Det har hänt mycket på litteraturhistorieskrivningens område under de senaste decennierna. Det finns en teoretisk medvetenhet om det svåra, för att inte säga omöjliga, i att skriva litteraturhistoria. Den som ger sig i kast med uppgiften konfronteras med grundläggande frågor om perspektiv, metod, urval och kontext - det går inte längre att bortse från att det ligger ett val och en värdering bakom dessa moment.

Ett nytt bidrag till litteraturhistorieskrivningens praktik (och därför principiellt viktig) är Nordens litteratur, redigerad av Margareta Petersson och Rikard Schönström.

Den beskrivs som en "systerbok" till Världens litteraturer som utkom 2011, även den med Petersson som redaktör. Vanligtvis brukar den svenska litteraturvetenskapen dela upp litteraturhistorien i en allmän och en svensk del, men här är det nordisk litteratur som utgör världslitteraturens komplement.

Begreppet Norden förstås i detta sammanhang som en föreställd gemenskap och ett mentalt rum snarare än som en geografisk plats. Föresatsen är att se svensk, dansk, finsk, grönländsk, isländsk, färöisk, norsk och samisk litteratur i växelverkan med varandra och inte som separata helheter.

Det här svarar enligt redaktörerna bättre mot den verkliga situationen; författare och litterära impulser har alltid rört sig över geografiska gränser. Gränserna mellan riken och stater har dessutom ritats om under historiens lopp, och överhuvudtaget är tänkandet i nationella termer ett arv från 1800-talet.

Litteraturen betraktas i en övergripande kontext där teknisk utveckling, krig, sociala förändringar, ekonomiska faktorer med mera spelar en viktig roll. Det är ett begränsat antal författare och texter som kommenteras, men fördelen är att det ger utrymme för en fördjupad beskrivning av fenomen och litteratur.

De författare och verk som behandlas hör huvudsakligen till de redan kanoniserade. Kapitlet om 1900-talets nordiska poesi avslutas till exempel med nobelpristagaren Tomas Tranströmer, vilket är ett värdigt slut såsom kapitelförfattaren Staffan Bergsten också konstaterar. Men naturligtvis får den avrundningen andra implikationer än om man gör som i antologin Svensk poesi (2016, red. Daniel Möller \& Niklas Schiöler), som avslutas med den unga iransk- 
svenska och politiskt engagerade Athena Farrokhzad. Ett liknande val skulle ha öppnat upp för en mera pluralistisk syn på vad nordisk lyrik är i dag.

Upplägget i Nordens litteratur är kronologiskt och avancerar från 800-talet till i dag. De totalt 17 medverkande (svenskar, och några andra nordbor) är specialister på olika delområden. Kristina Malmio är den som presenterar den finländska litteraturen, bortsett från barnlitteraturen som behandlas av Mia Österlund. I högre grad än i tidigare motsvarande verk vill man låta en komparativ hållning genomsyra hela boken.

Det är en god föresats, som dock försvåras av perspektivvalet och strukturen. Hur inledningskapitlet har rubricerats är redan en aning illavarslande: "Nordisk litteratur i ett svenskt perspektiv". Motiveringen är att det strikt taget inte finns några nordbor, bara svenskar, danskar, norrmän och så vidare, och att en nordisk litteraturhistoria måste skrivas ur något av dessa perspektiv. Redaktörerna är svenska, alltså får svensk litteratur större utrymme än de andra nordiska litteraturerna och framställningens "blick" på dessa präglas av den svenska utgångspunkten.

Men det är knappast uppenbart varför perspektivet skulle behöva vara markerat svenskt eller varför den svenska litteraturen skulle få större utrymme än de andra nordiska litteraturerna i ett verk som heter Nordens litteratur. Hellre än att bejaka en egen subjektivitet och egna föreställningar så vore det väl på sin plats att just här försöka utmana dylika begränsningar och föra en jämbördig dialog om principfrågor med andra nordiska forskare?

$\mathrm{Nu}$ blir det så att litteraturen i Sverige, Danmark och Norge till väsentliga delar behandlas som det allmänt nordiska medan litteraturen i Finland, Island, Grönland, Sápmi och Färöarna behandlas skilt. Skälen uppges vara språkliga men det visar bara att det saknas en djupare förståelse av den flerspråkighet man vill lyfta fram. Den finlandssvenska litteraturen passar knappast in i kategoriseringen heller. Hur oklart begreppet "finlandssvensk" är i ett svenskt perspektiv märks för övrigt i att det används på Runeberg och Topelius, vilket för en finländare ter sig som en omöjlig anakronism.

Följden av upplägget i "nordiskt" och "resten" blir också att ett konventionellt tänkande i centrum och periferi upprätthålls, vilket rimmar illa med det postkoloniala perspektiv som annars betonas. Kompositionen stöder de nationella gränsdragningar som både målsättningarna och litteraturen motsäger. Därför blir inkonsekvenserna så många i framställningen.

Man undrar varför redaktörerna inte i högre grad tänkt transnationellt och låtit empirin styra i stället för nationella tankemodeller? Den utveckling mot ökad modernisering och globalisering som beskrivs i de nationellt definierade kapitlen och som är en gemensam kontext för all senare nordisk litteratur talar också för en sådan mer gränsöverskridande lösning. Det sista kapitlet "Nordens litteratur i världen", skrivet av Rikard Schönström, är av just det slaget.

1900-talspoesin får ett eget kapitel, precis som barnlitteraturen. Den senare för att den uppvärderats, den förra för att den förlorat i prestige? Poesin har 
förvisso sina särskilda estetiska förutsättningar men man kan ändå fråga sig om inte det här valet bidrar till den marginalisering som inledningsvis påpekas: det faktum att allt färre läser poesi och att allt mindre upplagor trycks. Genom att avdela ett skilt kapitel för poesin där de existentiella och estetiska aspekterna dessutom dominerar är risken stor att genren ter sig mindre samhällstillvänd och angelägen för läsare i dag än vad den i själva verket är och kunde vara.

Men - det är lätt att komma med invändningar, och det är svårt att skriva litteraturhistoria. Nordens litteratur är utan tvekan ett innehållsrikt och värdefullt arbete, välskrivet och generöst illustrerat; en välkommen ansats att ge en samlad bild av den nordiska litteraturen över tid. Det komparativa greppet har ställvis gett gott resultat och i övrigt kanske det utelämnade, "felkategoriserade" och "felprioriterade" kan inspirera och provocera till fortsatt litteraturhistoriskt tänkande och skrivande.

Anna Möller-Sibelius 